\title{
Alkali-Activated Fly Ashes: Influence of Curing Conditions on Mechanical Strength
}

\author{
Filipe Almeida ${ }^{1}$, Nuno Cristelo ${ }^{2}$, Tiago Miranda ${ }^{3}$, Castorina S. Vieira ${ }^{4}$, \\ Maria de Lurdes Lopes ${ }^{5}$, Fernando Castro ${ }^{6}$ \\ ${ }^{1}$ Department of Civil Engineering, Faculty of Engineering, University of Porto, Porto, Portugal \\ (filipe.almeida@fe.up.pt) ORCID 0000-0002-0437-1314; 2Department of Engineering, \\ University of Trás-os-Montes e Alto Douro, Vila Real, Portugal (ncristel@utad.pt) ORCID 0000- \\ 0002-3600-1094; 3 Department of Civil Engineering, University of Minho, Guimarães, Portugal \\ (tmiranda@civil.uminho.pt) ORCID 0000-0003-4054-6860; ${ }^{4}$ CONSTRUCT-GEO, Department of \\ Civil Engineering, Faculty of Engineering, University of Porto, Porto, Portugal \\ (cvieira@fe.up.pt) ORCID 0000-0001-6328-4504; ${ }^{5}$ CONSTRUCT-GEO, Department of Civil \\ Engineering, Faculty of Engineering, University of Porto, Porto, Portugal (Icosta@fe.up.pt) \\ ORCID 0000-0002-2390-4825; 'Department of Mechanical Engineering, University of Minho, \\ Guimarães, Portugal (fcastro@dem.uminho.pt) ORCID 0000-0002-6674-3988
}

\begin{abstract}
Alkaline activation of fly ashes is a procedure that enables an alternative binder which has been receiving much interest by several research groups particularly on the manufacturing of mortars and concretes. The properties of the materials that are developed during the alkaline activation are influenced by the curing conditions (temperature and relative humidity). Another relevant facet related to the curing procedures is the possibility of carbonation occur, which may have an impact on the mechanical strength of the alkaline cements. In this research, several sets of curing conditions were tested to understand which one results in a higher strength and reveals carbonation. Uniaxial compressive strength tests were conducted to assess mechanical behavior. The outcome suggests that higher temperature and low relative humidity yields higher mechanical strength.
\end{abstract}

Author Keywords. Alkaline Activation, Fly Ashes, Alkaline Cement, Curing Conditions, Carbonation

Type: Research Article

ఠ Open Access $[\mathbf{b}$ Peer Reviewed $@$ CC BY

\section{Introduction}

Sustainable development is one of the current main priorities and one crucial issue is environmental responsibility. Since planet Earth natural resources are being depleted, it is important to guarantee a more rational management of these resources; the linear model of economic growth based on the principle "take-make-dispose" should be replaced by a circular model in which waste valorization is preferred.

The cement manufacturing industry is a major source of industrial pollution. The production of 1 ton of cement results in the emission of 1 ton of $\mathrm{CO}_{2}$ to the atmosphere (Davidovits 1991); in Portugal, this industry is the third larger greenhouse gas emitter (ZERO 2016).

Alkaline activation is a method used in the development of alternative binders in which the raw materials are industrial waste (e.g., fly ashes), it requires an activator (solution) and a precursor (solid state). This procedure may be described as an aluminosilicate hydration reaction, with alkaline or alkaline-earth substances (Pinto 2004). The alkaline activation process can be branched in three different stages: a) dissolution of the amorphous phase 
present in the raw material and nucleation of the resulting species; b) precipitation of the nuclei after reaching critical mass; c) crystallization of the nuclei. The strength gain rate significantly depends on the type of main element present in the precursor, as well as on the total volume of vitreous content (Cristelo et al. 2016a).

The amorphous gel that is created relies on the presence of calcium; without calcium, a $\mathrm{N}-\mathrm{A}-\mathrm{S}-\mathrm{H}$ type gel is formed, but when higher calcium percentages exists, both N-A-S-H and $\mathrm{C}-\mathrm{S}-\mathrm{H}$ type gel can be detected, similar to one that occurs during the cement hydration. High compression strength, high durability (in particular during acid attacks), good stability under high temperatures and heavy metal retention capacity are some of the properties of the resulting materials (Cristelo et al. 2016b).

The initial research with alkaline cements, held during de 1960s, resulted in major applications in hydroelectric engineering, roads, civil engineering and mining industry. This research corroborates the high performance of the concrete manufactured with this type of cement (Palomo et al. 2014). The high compressive strength of mortars or concretes that have in their composition geopolymeric mixtures is a noteworthy feature in this research (FernándezJiménez and Palomo 2004; Ryu et al. 2013; Davidovits 1991).

The curing conditions (temperature and relative humidity) have a significant role on the properties of the resulting materials of the alkaline activation. Palomo et al. (2007) points out that in some laboratory tests the compressive strength of mortars achieved $100 \mathrm{MPa}$, with a

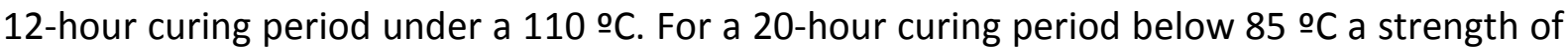
$70 \mathrm{MPa}$ is achieved, however the strength could be increased to $80 \mathrm{MPa}$ after 28 days.

Another aspect that must be considered is that the curing procedures may lead to a carbonation process that could negatively affect the development of the mechanical strength of alkaline cements. In an initial stage the carbonation implicate a reduction of $\mathrm{pH}$ levels that leads to a reduction of the ashes activation rate and a reduction on the mechanical strength (Criado, Palomo, and Fernández-Jiménez 2005).

This research aims to assess the modifications on mechanical strength of alkali-activated fly ashes regarding different curing conditions (temperature and relative humidity) and to comprehend in which conditions carbonation occurs. Uniaxial compressive strength tests were used to assess the mechanical strength of the alkali-activated fly ashes.

\section{Materials and Methods}

\subsection{Materials characterisation}

Within the framework of this research several mixtures containing fly ashes, sodium hydroxide and sodium silicate were prepared.

The fly ashes (Figure 1), which chemical composition is on Table 1, were collected from the portuguese thermoelectric power plant of Pêgo and according to the standard ASTM C618-15 (ASTM 2015) conform on F class. The X-ray diffraction (XRD) method was used to identify the mineral phases on the fly ashes. The results of this analysis, which is shown on Figure 2 , demonstrates that the main mineral phases are quartz $(\mathrm{Q})$ and mullite $(\mathrm{Mu})$.

The SEM image shown on Figure 1b was obtained using a FEI QUANTA - 400 electronic microscope, with a tungsten filament electron source and $30 \mathrm{kV}$ accelerating voltage. The analyses were conducted in low vacuum mode (1.3 mbar), avoiding the deposition of a conductive layer. The device is coupled with an X-ray energy dispersive spectrometry system (EDS) from EDAX. 
A CuK $\alpha(\lambda=1.54 \AA$ A $)$ BRUKER D8 Advance diffractometer (Lynxeye detector, $3 \mathrm{~mm}$ antiscatter slit, (0.5\%) Ni K-beta filter, $2 \theta$ angles, 50 to 60 ㅇ) was used to make XRD analysis (Medina et al. 2017).
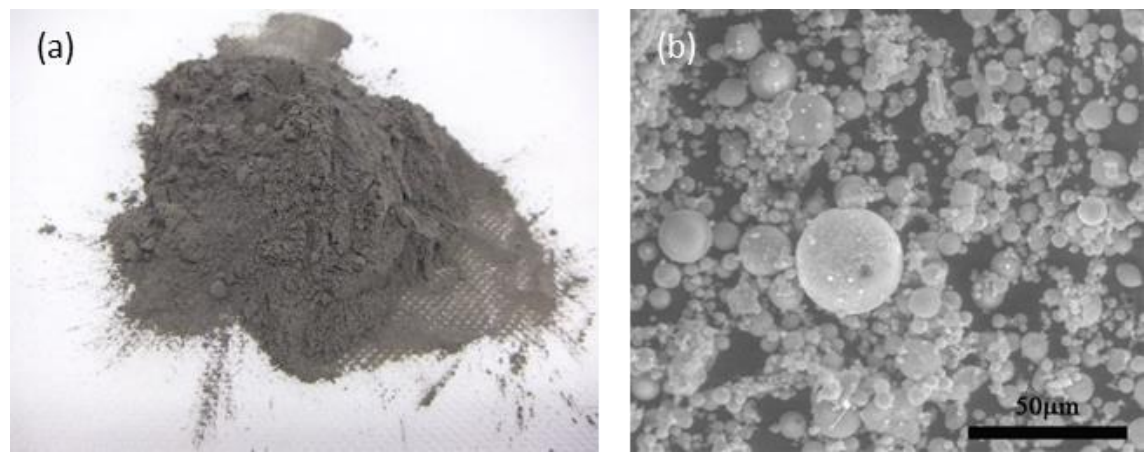

Figure 1: Fly ashes: a) general view; b) SEM image

\begin{tabular}{ccccccccccc}
\hline Oxide & $\mathrm{SiO}_{2}$ & $\mathrm{Al}_{2} \mathrm{O}_{3}$ & $\mathrm{Fe}_{2} \mathrm{O}_{3}$ & $\mathrm{CaO}$ & $\mathrm{K}_{\mathbf{2}} \mathrm{O}$ & $\mathrm{TiO}_{2}$ & $\mathbf{M g O}$ & $\mathrm{Na}_{2} \mathrm{O}$ & $\mathrm{SO}_{3}$ & $\mathbf{P}_{2} \mathrm{O}_{5}$ \\
\hline $\mathrm{FA}$ & 55.27 & 21.77 & 11.15 & 2.85 & 2.82 & 1.58 & 1.37 & 0.93 & 1.55 & 0.70 \\
\hline \multicolumn{8}{c}{ Table 1: Chemical composition of the Fly Ash - FA (\% wt) }
\end{tabular}

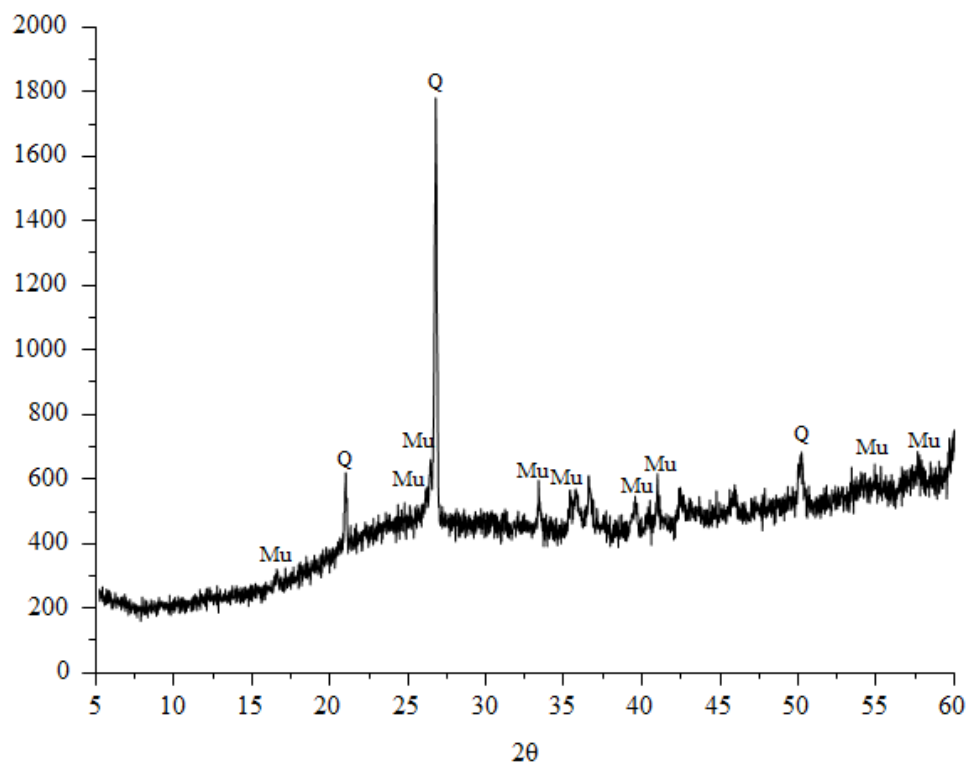

Figure 2: Diffractogram of fly ashes

The activator used in this work was composed of sodium hydroxide and sodium silicate. The sodium hydroxide, with a specific gravity of 2.13 at 20 ㅇ (99 wt.\%), was supplied in pellets and was dissolved in distilled and deionised water to obtain a 10.0 molal concentration. The sodium silicate was acquired in solution and had a unit weight of $1.464 \mathrm{~g} / \mathrm{cm}^{3}$ at $20 \mathrm{o}$, a $\mathrm{SiO}_{2} / \mathrm{Na}_{2} \mathrm{O}$ weight ratio of 2.0 (molar oxide ratio of 2.063 ) and a $\mathrm{Na}_{2} \mathrm{O}$ concentration in the solution of $13.0 \%$.

\subsection{Test specimens preparation and curing conditions}

For this research, 10 series of 3 prismatic test specimens with $40 \mathrm{~mm} \times 40 \mathrm{~mm} \times 160 \mathrm{~mm}$ for each curing conditions were made using a liquid/solid (L/S) ratio of 0.20 (the workability of the mixture was the best using this ratio) (Table 2).

\begin{tabular}{ccccccccccc}
\hline Series & A & B & C & D & E & F & G & H & I & J \\
\hline $\mathrm{T}(\mathrm{o}$ C) & 80 & 80 & 80 & 60 & 60 & 60 & 40 & 40 & 40 & $\mathrm{CA}$ \\
$\mathrm{RH}(\%)$ & 20 & 50 & 80 & 20 & 50 & 80 & 20 & 50 & 80 & CA \\
\hline
\end{tabular}

Table 2: Sets of curing conditions tested 
The materials that make the mixtures were added to a canister to apply a homogenization process during a period of 3 minutes (Figure 3).

The test specimens were inserted in casts manufactured according to the standard NP EN 1961:2017 (IPQ 2017), which allowed the simultaneous preparation of 3 test specimens that composed each series. Then, the casts were placed on a vibration table for a period of 30 seconds.

The test specimens of series A through I had a 20-hour curing period in a climate chamber WEISS TECHNIK WK11-340; test specimens from J series (CA) remained in a room at a stable temperature and relative humidity of $18.4 \stackrel{\circ}{\circ} \mathrm{C}$ and $67.4 \%$, respectively. The room conditions were assessed by a portable device TESTO $605-\mathrm{H} 1$ with a measuring range for humidity of 5 to $95 \%$ and an accuracy of $\pm 3 \%$, and with a temperature measuring range of 0 to $50 \stackrel{\circ}{ } \mathrm{C}$ and an accuracy of $\pm 0.5 \stackrel{\circ}{\circ}$.

The test specimens' series A through I were extracted from the casts after being removed from the climate chamber, then the test specimens were enveloped with plastic paraffin film to avoid humidity losses; later, the test specimens were stored in the room mentioned for J series until the date of the uniaxial compressive strength (UCS) tests. The J series were maintained on the casts until the end of the curing period.

All test specimens were tested with a curing period of 7 days.

After the curing period, all 3 test specimens of each series were sliced into 9 cubes with a 40 $\mathrm{mm}$ edge, these cubes were submitted to UCS tests.

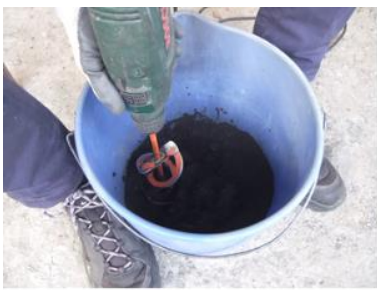

(a)

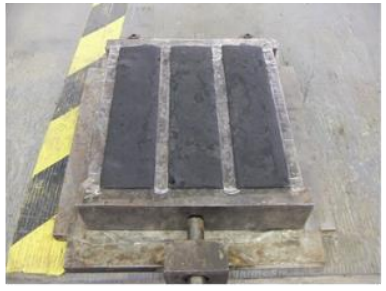

(b)

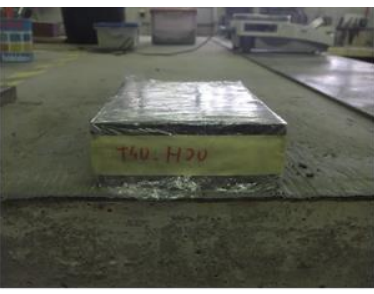

(c)

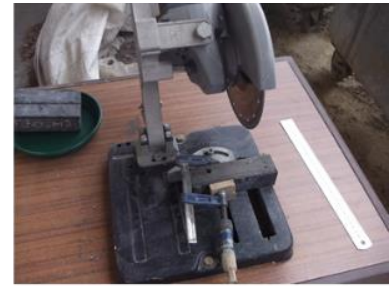

(d)

Figure 3: Test specimens' preparation: a) homogenization process; b) test specimens inside the cast; c) protection of the test specimens; $d$ ) test specimens slicing process

\subsection{Uniaxial compressive strength (UCS) tests}

The UCS tests (Figure 4) were carried out on a servo-hydraulic testing machine, fitted with a OMNI INSTRUMENTS $50 \mathrm{kN}$ load cell. The displacements were acquired from a APPLIED MEASUREMENTS LVDT with a stroke of $\pm 50 \mathrm{~mm}$. These tests were carried out under monotonic displacement control at a rate of $0.4 \mathrm{~mm} / \mathrm{min}$ until the test specimens rupture. All test specimens were measured and weighted before the beginning of UCS tests and stressstrain curves were drawn for each UCS tests. Compression strength values showed in this paper represent the average of 9 tested specimens. 


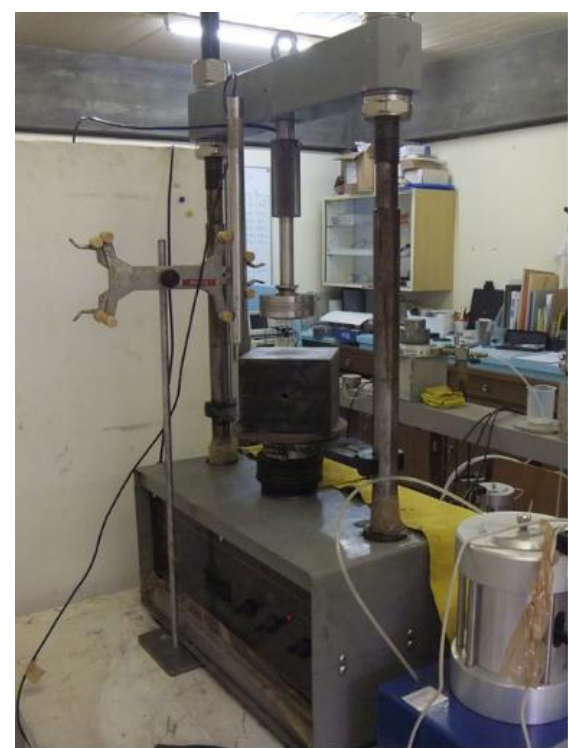

(a)

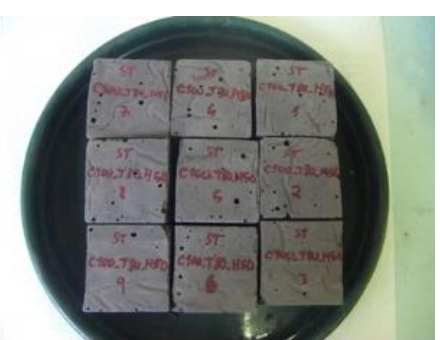

(b)

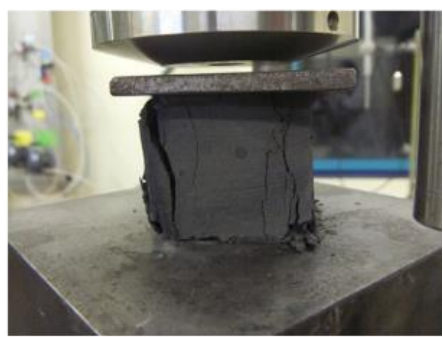

(c)

Figure 4: UCS testing: a) servo-hydraulic testing machine; b) cubes before UCS tests; c) test specimen ruptured

\section{Experimental results and discussion}

\subsection{Mechanical behavior}

The UCS values from each tested series are shown in Figure 5 . The A series achieved the best results, with a UCS value of $2.89 \mathrm{MPa}$. The test specimens of $A$ series were submitted to a 20 hour curing period on a climate chamber with temperature and relative humidity of 80 으 $\mathrm{C}$ and $20.0 \%$, respectively. Regarding the results, it can be widely said that higher strength is achieved when the temperature is high and relative humidity is low.

The exception to this trend are series $D, E$ and $F$ in which curing temperature was $60 \circ C$; for these 3 series; E series, with a curing relative humidity of $50 \%$ had the best results. It is emphasized the low strength $(0.46 \mathrm{MPa})$ of $J$ series $(\mathrm{CA})$ in which both temperature and relative humidity maintained constant during the 7 days curing period.

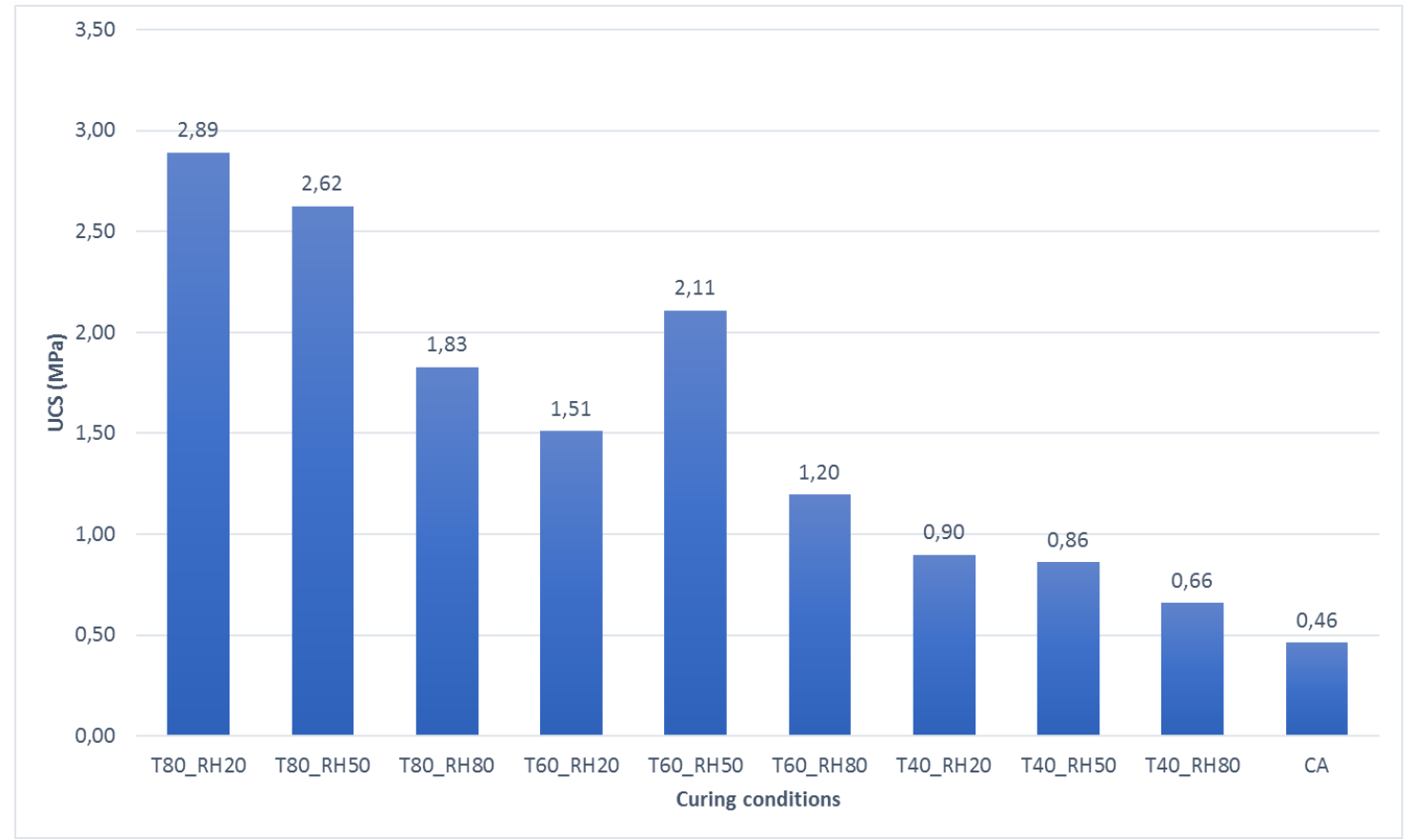

Figure 5: UCS tests results 


\subsubsection{Influence of temperature}

The graph in Figure 6 clearly shows that rising the temperature leads to higher compressive strength. While relative humidity is $80 \%$, strength increases $81.6 \%$ and $52.6 \%$ when

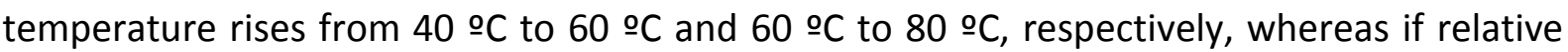
humidity is $50 \%$, strength increases $144.7 \%$ and $24.5 \%$, respectively for the same variation of temperature and at a relative humidity of $20 \%$, strength increases $68.2 \%$ and $91.4 \%$, respectively.

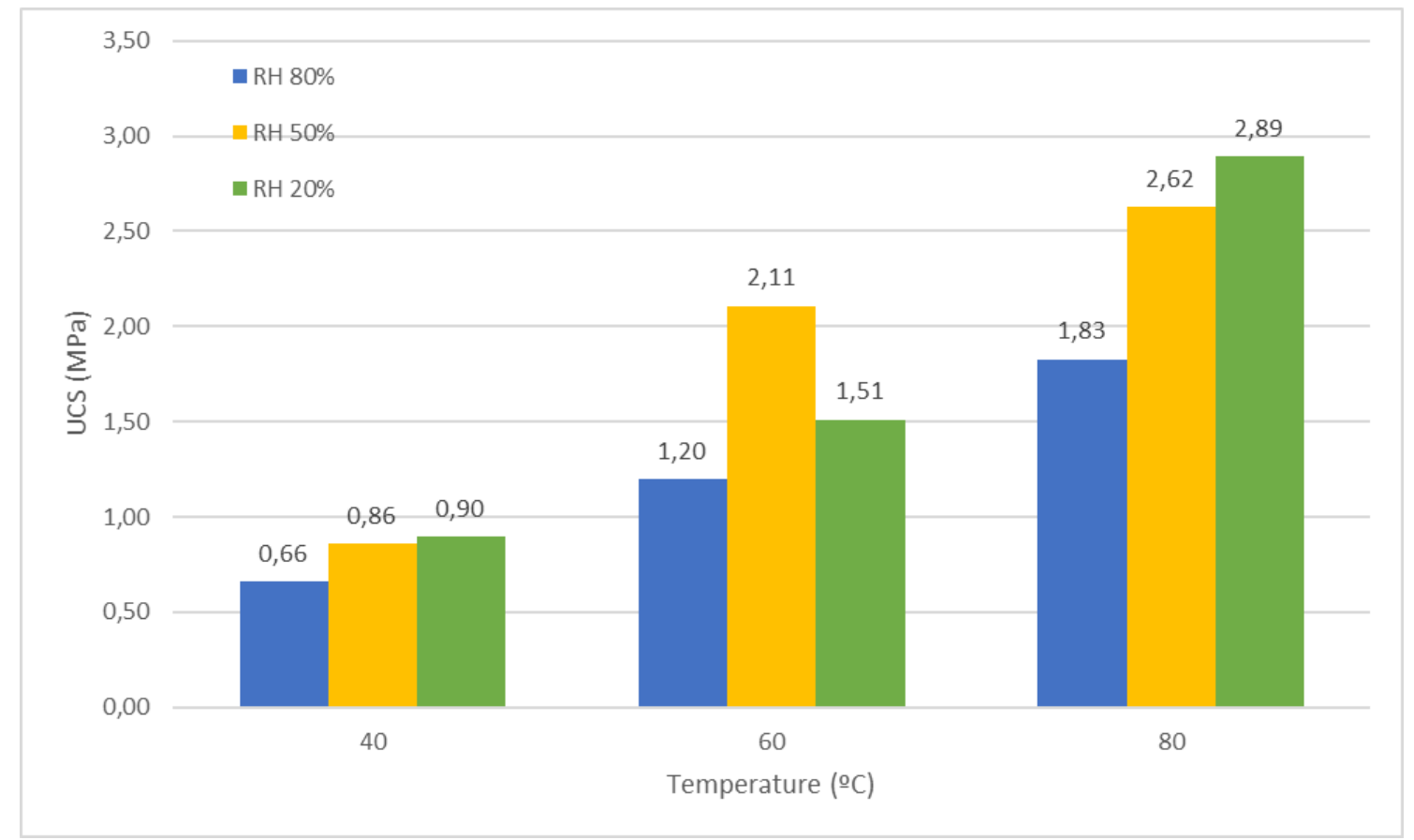

Figure 6: Influence of temperature on compressive strength

Except for $E$ series there is a linear strength growth behavior, as shown in Figure 6. Hence, $E$ series (temperature: 60 ㄷ; r relative humidity: $50 \%$ ) requires a deeper analysis to understand and discuss the outcome achieved.

\subsubsection{Influence of humidity}

The graph in Figure 7 shows an increase strength as the relative humidity diminishes. While temperature is $40 \circ \mathrm{C}$, strength increases $30.7 \%$ and $4.2 \%$ when relative humidity decreases from $80 \%$ to $50 \%$ and $50 \%$ to $20 \%$, respectively, whereas if temperature is $80 \circ \mathrm{C}$, strength increases $43.6 \%$ and $10.1 \%$, respectively for the same variation of relative humidity. If the temperature is $60 \circ \mathrm{C}$, this behavior trend is disrupted: when relative humidity decreases from $80 \%$ to $50 \%$, strength increases $76.1 \%$ but decreases $28.4 \%$ when relative humidity diminishes from $50 \%$ to $20 \%$.

Once again, the outcome of $E$ series contradicts the trend established from the other series. 


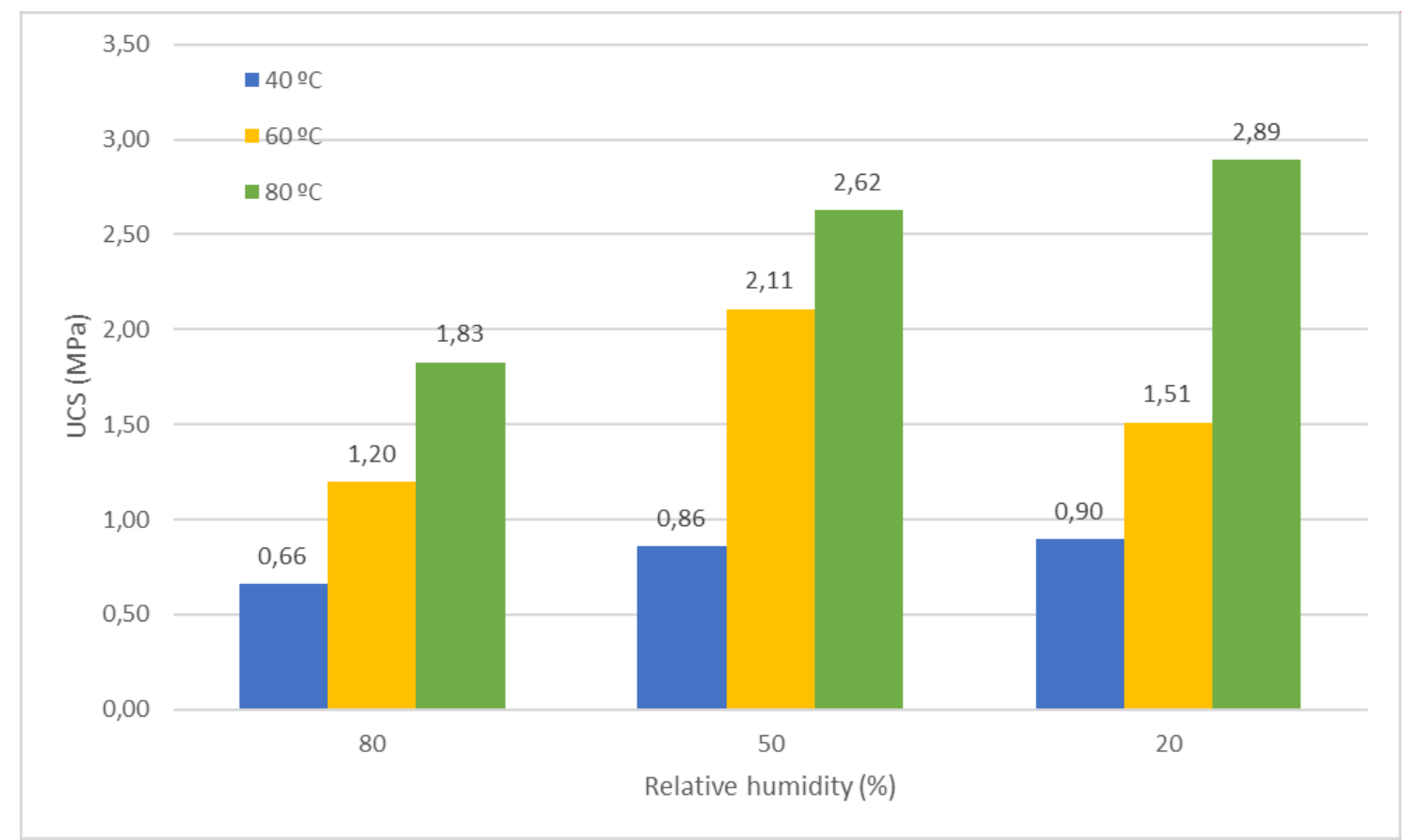

Figure 7: Influence of relative humidity on compressive strength

\subsubsection{Temperature and humidity ratios}

The graphs in the Figures 8 and 9 show UCS values in function of temperature/relative humidity $(\mathrm{T} / \mathrm{RH})$ and relative humidity/temperature $(\mathrm{RH} / \mathrm{T})$ ratios, respectively. The curves shown in Figure 10 confirm that a larger ratio T/RH leads to higher UCS values. If the UCS values for when relative humidity is $20 \%$ are disregarded (Figure 10b), a high coefficient of determination $\left(R^{2}\right)$ is suitable for the trendline created by the remaining UCS values.

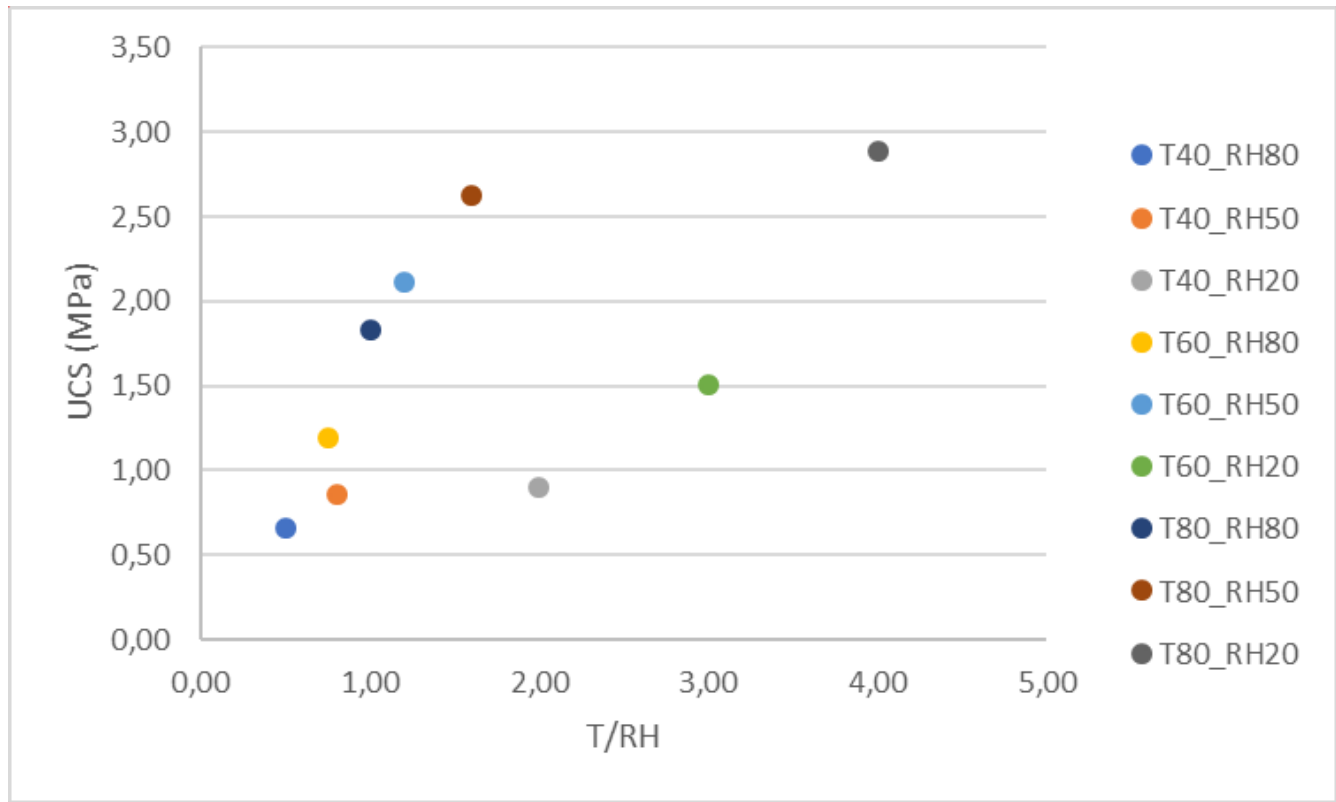

Figure 8: UCS values in function of $\mathrm{T} / \mathrm{RH}$ ratio 


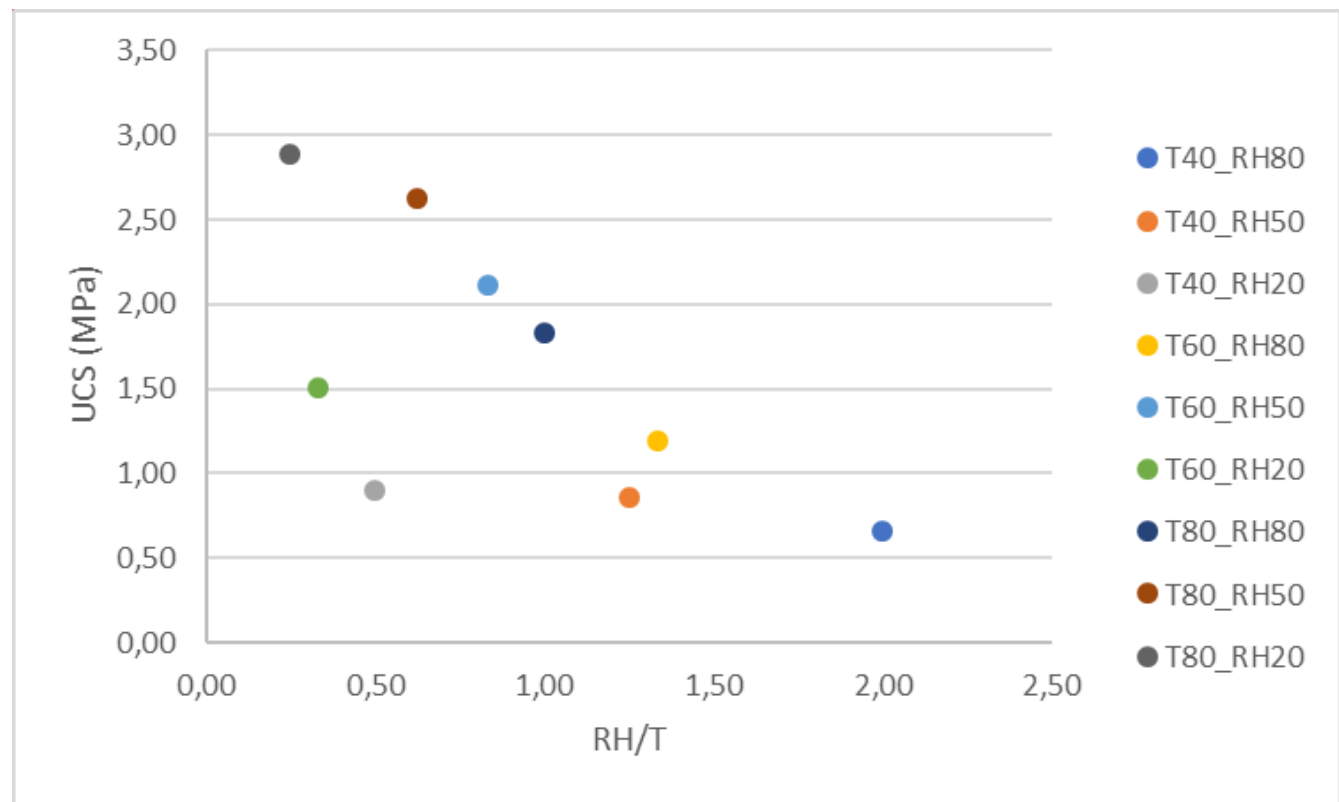

Figure 9: UCS values in function of $\mathrm{RH} / \mathrm{T}$ ratio

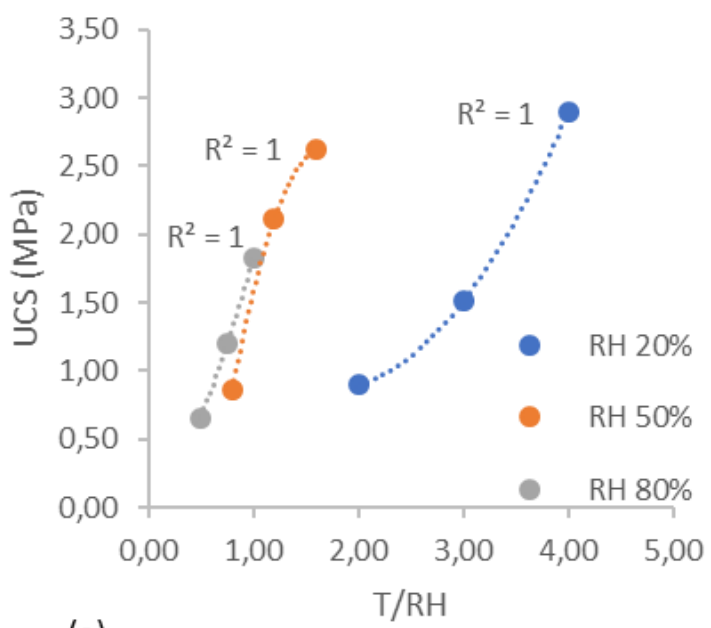

(a)

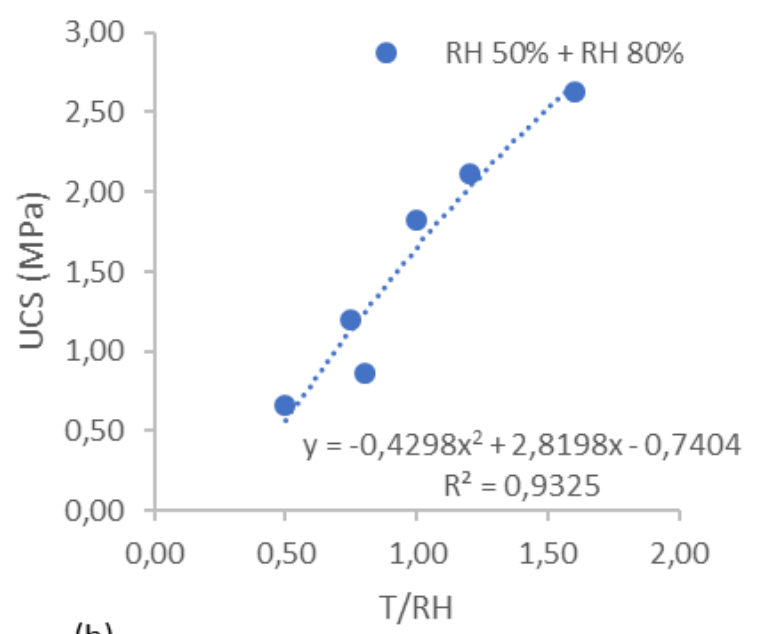

(b)

Figure 10: UCS values in function of T/RH ratio: a) all UCS values; b) UCS values of RH $50 \%$ and RH $80 \%$ series

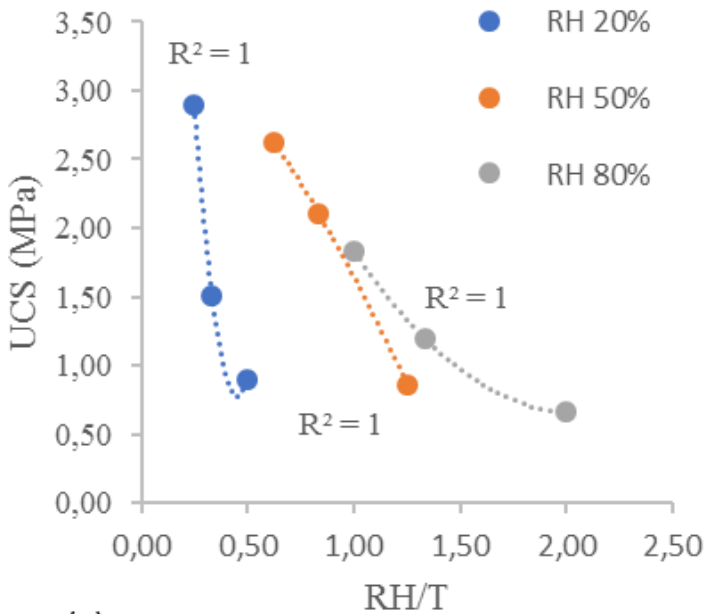

(a)

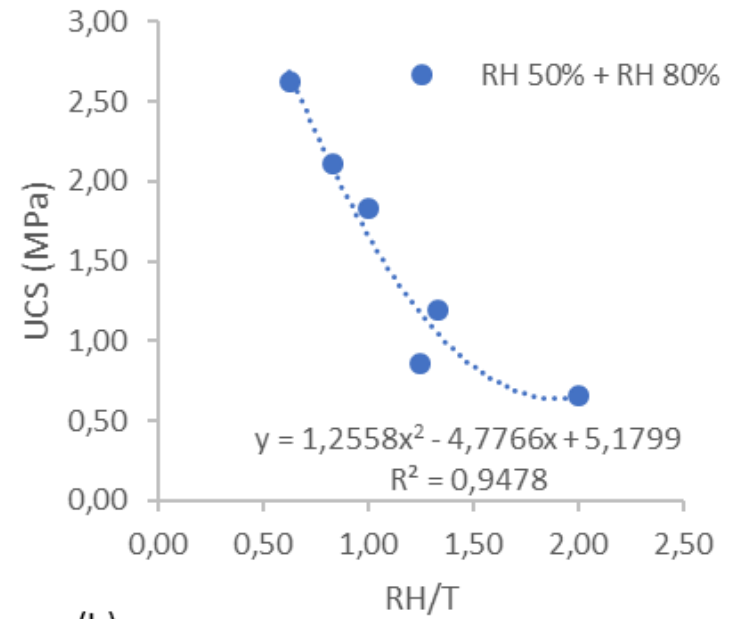

(b)

Figure 11: UCS values in function of RH/T ratio: a) all UCS values; b) UCS values of RH $50 \%$ and $\mathrm{RH} 80 \%$ series 
As demonstrated in Figure 11, a high RH/T ratios leads to low UCS values. Once again, because the UCS values for the series with relative humidity of $20 \%$ (Figure 11b) are omitted, a high coefficient of determination $\left(R^{2}\right)$ is suitable for the trendline created by the remaining UCS values.

\subsubsection{Achieved results analysis}

The UCS values achieved were considerably low. After a period of consideration, distrust was installed regarding the expiration date of the sodium silicate handled in this work. Hence, a new batch of the mixture was made using a sodium silicate with the same characteristics but within the recommended period of utilization. This new sodium silicate affected the workability of the mixture, compelling an adjustment in the L/S ratio to 0.21 , a higher L/S ratios lead to a more viscous mixture. The test specimens resulting from this mixture were submitted at the same curing conditions as $D$ series (temperature: $60 \stackrel{\circ}{ }$; relative humidity: $20 \%)$.

The outcome UCS value was $18.90 \mathrm{MPa}$, which is significantly higher than $1.51 \mathrm{MPa}$ from the initial tests, corroborating the initial distrust regarding the sodium silicate.

\subsection{Carbonation}

The sodium carbonation take place when this element, by diffusion, contacts the atmosphere and it was substantiated that carbonation occurs for the test specimens of J series (CA) and $\mathrm{H}$ series. It should be stated that the carbonation was more evident in the $\mathrm{J}$ series than on the $\mathrm{H}$ series.

Carbonation leads to white crystals emerge from the surface of the test specimens as shown on Figure 12. According to Criado, Palomo, and Fernández-Jiménez (2005), when the test specimens are in contact with the atmosphere, carbonation occurs more rapidly, but as the test specimens became more compact, the $\mathrm{CO}_{2}$ infiltration on the hard matrix come to be more difficult.
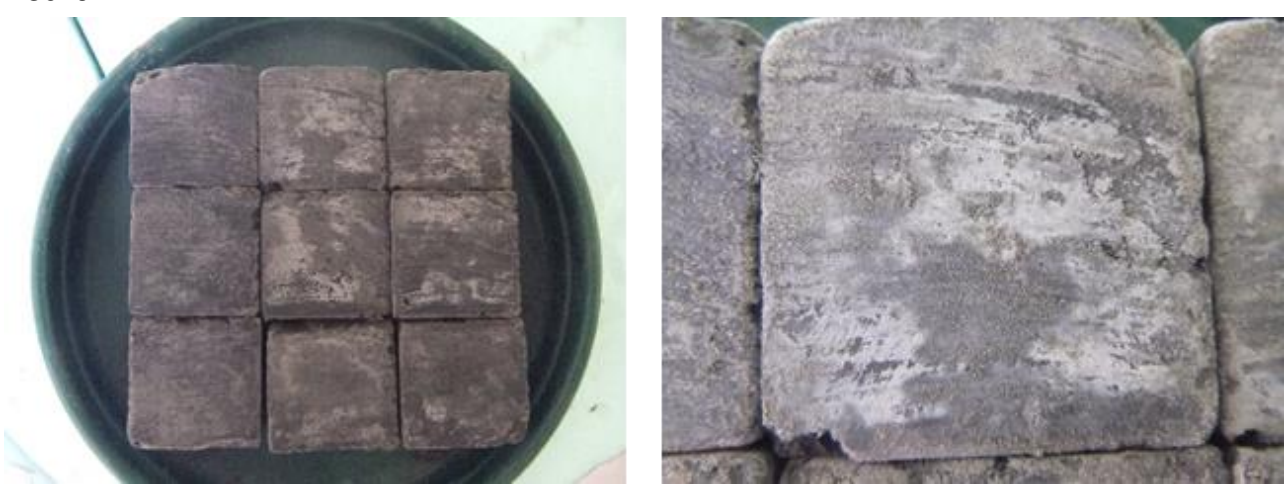

Figure 12: Carbonation on test specimens from J series

\section{Conclusions}

The alkaline cements are an alternative binder, which properties are influenced by curing conditions, with a wide range of practical applications.

The present research aimed to assess which curing conditions leads to higher compressive strength and display carbonation on alkali-activated fly ashes.

Except for E series, which curing temperature was $60 \stackrel{\circ}{ } \mathrm{C}$ and relative humidity was $50 \%$, the

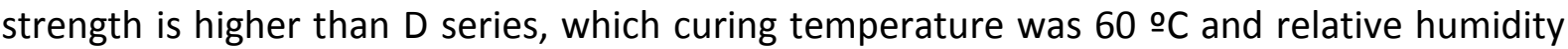
was $20 \%$. Hence, it is important to scrutinize why these curing conditions present these results. 
The best strength values were attained by A series, which curing temperature was $80 \circ \mathrm{C}$ and relative humidity was $20 \%$. The results achieved suggest that higher temperature/relative humidity ratios lead to higher compressive strength.

Carbonation developed on the $\mathrm{J}$ and $\mathrm{H}$ series, which curing temperature and relative humidity were $18.4 \stackrel{\circ}{\circ}$, $67.4 \%$ and $40 \stackrel{\circ}{\circ}, 50 \%$, respectively. Ergo, carbonation process can be avoided on alkali-activated fly ashes when curing conditions are controlled.

\section{References}

ASTM. 2015. ASTM C618-15: Standard specification for coal fly ash and raw or calcined natural pozzolan for use in concrete. West Conshohocken, PA, United States of America: ASTM International.

Criado, M., A. Palomo and A. Fernández-Jiménez. 2005. "Alkali activation of fly ashes. Part 1: Effect of curing conditions on the carbonation of the reaction products". Fuel 84 (16):20482054. Accessed April 7, 2017. DOI: 10.1016/j.fuel.2005.03.030.

Cristelo, N., P. Tavares, E. Lucas, T. Miranda and D. Oliveira. 2016a. "Quantitative and qualitative assessment of the amorphous phase of a Class $\mathrm{F}$ fly ash dissolved during alkali activation reactions - Effect of mechanical activation, solution concentration and temperature". Composites Part B: Engineering 103:1-14. Accessed April 7, 2017. DOI: 10.1016/j.compositesb.2016.08.001.

Cristelo, N., C. S. Vieira, P. Filho, F. Almeida and M. L. Lopes. 2016b. "Avaliação laboratorial da resistência mecânica de RCD estabilizados com cinzas ativadas para aplicações geotécnicas [Experimental evaluation of the compressive of CDW stabilised with activated fly ash for geotechnical applications]". Paper presented at 15. Congresso Nacional de Geotecnia, Porto, Portugal, June 19-23, 2016.

Davidovits, J. 1991. "Geopolymers - inorganic polymeric new materials". Journal of Thermal Analysis 37 (8):1633-1656. Accessed April 7, 2017. DOI: 10.1007/bf01912193.

Fernández-Jiménez, A. and A. Palomo. 2004. "Alkaline activation of fly ashes. Manufacture of concrete not containig Portland cement". Paper presented at PRO 40: International RILEM Conference on the Use of Recycled Materials in Building and Structures, Barcelona, Spain, November 8-11, 2004.

IPQ. 2017. NP EN 196-1:2017: Métodos de ensaio de cimentos - Parte 1: Determinação das resistências mecânicas [Methods of testing cement - Part 1: Determination of strength]. Lisboa, Portugal: Instituto Português da Qualidade.

Medina, G., I. F. Sáez del Bosque, M. Frías, M. I. Sánchez de Rojas and C. Medina. 2017. "Granite quarry waste as a future eco-efficient supplementary cementitious material (SCM): Scientific and technical considerations". Journal of Cleaner Production 148:467-476. Accessed April 7, 2017. DOI: 10.1016/j.jclepro.2017.02.048.

Palomo, A., A. Fernández-Jiménez, C. López Hombrados and J. Lleyda. 2007. "Railway sleepers made of alkali activated fly ash concrete". Revista Ingeniería de Construcción 22 (2):75-80. Accessed April 7, 2017. DOI: 10.4067/s0718-50732007000200001.

Palomo, A., P. Krivenko, I. Garcia-Lodeiro, E. Kavalerova, O. Maltseva and A. FernándezJiménez. 2014. "A review on alkaline activation: New analytical perspectives". Materiales de Construccion 64 (315):e022. Accessed April 7, 2017. DOI: 10.3989/mc.2014.00314.

Pinto, A. 2004. "Sistemas ligantes obtidos por activação alcalina do metacaulino". PhD thesis. Escola de Engenharia, Universidade do Minho. 
Ryu, G. S., Y. B. Lee, K. T. Koh and Y. S. Chung. 2013. "The mechanical properties of fly ashbased geopolymer concrete with alkaline activators". Construction and Building Materials 47:409-418. Accessed April 7, 2017. DOI: 10.1016/j.conbuildmat.2013.05.069.

ZERO. 2016. "Ranking das empresas e setores com mais emissões de gases com efeitos de estufa". Accessed April 5, 2017. http://zero.ong/zero-divulga-ranking-das-empresas-esetores-com-mais-emissoes-de-gases-com-efeito-de-estufa/\#_ftn1.

\section{Acknowledgements}

This work has been performed within the framework of the research project BGCTM/UTAD72/2016 "GEO-DESIGN - Artefatos para hotelaria e mobiliário urbano incorporando resíduos" funded by FEDER - Fundo Europeu de Desenvolvimento Regional through Norte 2020 Programa Operacional Regional do Norte 2014/2020. 